\title{
Familial Mediterranean fever patients with prominent musculoskeletal symptoms may be classified in a distinct subgroup
}

\author{
Kas-iskelet bulguları olan Ailevi Akdeniz ateși hastaları farklı bir alt grupta sınıflanabilir
}

(1) Mehmet Engin Tezcan

Kartal Dr. Lütfi Kırdar City Hospital, Clinic of Rheumatology, İstanbul, Turkey

\begin{abstract}
Some of Familial Mediterranean fever (FMF) patients suffer from several different musculoskeletal symptoms similar to spondyloarthropathy. Colchicine is generally ineffective in treating these symptoms, unlike its effects on serositis. Therefore, these patients can be classified into a different disease class: The musculoskeletal variant of FMF. Additionally, studies should be conducted on these patients to evaluate both the disease characteristics of this subgroup and treatment options for the variant.
\end{abstract}

Keywords: Familial Mediterranean fever, spondyloarthropathy, musculoskeletal symptoms

\section{Dear Editor,}

Familial Mediterranean fever (FMF) is an autoinflammatory disease characterized by recurrent fever and serositis attacks. ${ }^{[1]}$ Three quarters of the patients with FMF have some type of musculoskeletal symptoms. ${ }^{[2]}$ Herein, there may be two distinct clinical spectrums in the FMF patients with musculoskeletal involvement. Firstly, some FMF patients may suffer from recurrent attacks of acute, non-erosive, self-resolving monoarthritis such as serositis attacks. ${ }^{[3]}$ Others have musculoskeletal features, which are usually chronic and persistent. Here, $5 \%$ of patients may have permanent arthritis, especially in the large lower extremity joints. ${ }^{[4]}$ In addition, other musculoskeletal features including sacroilitis, spinal involvement and enthesitis are not uncommon in FMF patients. ${ }^{[5,6]}$ It was recently shown

\section{Öz}

Birçok Ailevi Akdeniz ateși (AAA) hastası spondiloartropatide görülen tarzda farklı kas-iskelet sistemi semptomları gösterebilir. Kolșisin, genelde bu semptomların tedavisinde, serozit üzerindeki etkisine göre yetersiz kalmaktadır. Bu yüzden kas-iskelet sistemi bulguları ön planda olan hastalar farklı bir alt grupta değerlendirilebilir: AAA'nın kas iskelet varyantı. Ek olarak, bu varyantın hastalık karakterlerini ve tedavi seçeneklerini belirleyecek çalıșmaların organize edilmesi faydalı olacaktır.

Anahtar Kelimeler: Ailevi Akdeniz ateși, spondiloartropati, kasiskelet semptomları

that exertional leg pain is also a sign of lower extremity enthesitis. ${ }^{[7]}$ All these musculoskeletal features are often found together and have been associated with more severe disease. ${ }^{[8]}$ Therefore it would be speculated that, like Behçet syndrome, ${ }^{[9]} \mathrm{FMF}$ patients with pronounced musculoskeletal symptoms can be classified under the musculoskeletal or spondyloarthropathy ( $\mathrm{SpA}$ ) subgroup of the disease. In addition, there are many studies in the literature presenting patients with both FMF and SpA. ${ }^{[10,11]}$ However, we do not currently know whether these patients are FMF patients with SpA or whether they suffer from FMF with predominant musculoskeletal features. Recently, it has been shown that ankylosing spondilitis (AS) patients with FMF have a different clinical picture than only AS patients. ${ }^{[12]}$ Moreover, FMF patients with dominant musculoskeletal features have higher disease activity scores and more frequent, intense and

İletișim / Correspondence:

Mehmet Engin Tezcan MD, Kartal Dr. Lütfi Kırdar City Hospital, Clinic of Rheumatology, İstanbul, Turkey

Tel.: +90 2164583000 E-posta: engintez@yahoo.com ORCID ID: orcid.org/0000-0002-1753-4936

Geliș Tarihi / Received: 15.05.2021 Kabul Tarihi / Accepted: 15.09.2021

Atıf / Cite this article as: Tezcan ME. Familial Mediterranean fever patients with prominent musculoskeletal symptoms may be classified in a distinct subgroup.

Ulus Romatol Derg 2021;13(3):140-146

๑Telif Hakkı 2021 Türkiye Romatoloji Derneği / Ulusal Romatoloji Dergisi, Galenos Yayınevi tarafından basılmıștır.

${ }^{\odot}$ Copyright 2021 by the Turkish Society for Rheumatology / Journal of Turkish Society for Rheumatology published by Galenos Publishing House. 
longer serositis attacks although these are not SpA signs. ${ }^{[8]}$ Also, FMF patients with SpA findings have lower frequency of HLAB27 positivity as compared to SpA patients. ${ }^{[13]}$ Lastly, FMF patients with AS have lower frequency of uveitis, as an example of extra articular features of SpA. ${ }^{[12]}$ Therefore, I speculate that some FMF patients may have SpA-like phenotypes through the MHC class I type additive immune system. ${ }^{[14]}$ According to several studies, M694 V mutations are the most frequent MEFV mutations in FMF patients with SpA findings or SpA diagnosis. ${ }^{[1,15]}$ Since colchicine is not always successful in treating musculoskeletal symptoms of FMF, other treatment options may be considered early in these patients. According to EULAR recommendations for the management of FMF, disease modifying anti-rheumatic drugs, intra-articular steroid injections and biologics may be applied to the patients with chronic arthritis. ${ }^{[16]}$ Therefore, those drugs may be administered to the patients with musculoskeletal features. Additionally, studies on FMF have been conducted on the whole group, without focusing on FMF patients with specific disease characteristics such as musculoskeletal symptoms. In addition, definitions of colchicine resistance do not include musculoskeletal features that are unresponsive to colchicine. ${ }^{[9]}$ Therefore, studies focusing on this FMF subgroup are needed to establish the treatment approach for musculoskeletal features of FMF patients.

\section{Ethic}

Peer-review: Externally peer-reviewed.

Financial Disclosure: The author declared that this study received no financial support.

\section{References}

1. Ben-Chetrit E, Levy M. Familial Mediterranean fever. Lancet 1998;351:659-64.

2. Borman P, Gokoglu F, Tasbas O, Yilmaz M, and Yorgancioglu ZR. Familial Mediterranean fever-related spondyloarthropathy. Singapore Med J 2009;50:e116-9.

3. Mattiassich G, Semlitsch G, Nadler K, Rainer F. Familial Mediterranean fever without fever as a cause of monoarthritis. BMJ Case Rep 2013;2013:bcr2012008395. doi: 10.1136/ bcr-2012-008395.
4. Bodur H, Ucan H, Seckin S, Seckin U, Gunduz OH. Protracted familial Mediterranean fever arthritis. Rheumatol Int 1999;19:71-3.

5. Aydin F, Ozcakar ZB, Cakar N, et al. Sacroiliitis in Children With Familial Mediterranean Fever. J Clin Rheumatol 2019;25:69-73.

6. Tufan A, Mercan R, Tezcan ME, et al. Enthesopathy in patients with familial Mediterranean fever: increased prevalence in M694 V variant. Rheumatol Int 2013;33:1933-7.

7. Eshed I, Rosman Y, Livneh A, et al. Exertional leg pain in familial Mediterranean fever: a manifestation of an underlying enthesopathy and a marker of more severe disease. Arthritis Rheumatol 2014;66:3221-6.

8. Sen N, Yilmaz M, Mercan R, et al. Enthesitis may be one of the signs of severe disease in familial Mediterranean fever. Clin Rheumatol 202;40:1479-85.

9. Tunc R, Keyman E, Melikoglu M, Fresko I, Yazici H. Target organ associations in Turkish patients with Behcet's disease: a cross sectional study by exploratory factor analysis. J Rheumatol 2002;29:2393-6.

10. Yildiz M, Adrovic A, Tasdemir E, et al. Evaluation of co-existing diseases in children with familial Mediterranean fever. Rheumatol Int 2020;40:57-64.

11. Atas N, Armagan B, Bodakci E, et al. Familial Mediterranean fever is associated with a wide spectrum of inflammatory disorders: results from a large cohort study. Rheumatol Int 2020;40:41-8.

12. Yazici A, Ozdemir Isik O, Temiz Karadag D, Cefle A. Are there any clinical differences between ankylosing spondylitis patients and familial Mediterranean fever patients with ankylosing spondylitis? Int J Clin Pract 2021;75:e13645. doi: 10.1111/ijcp.13645.

13. Sonmez HE, Batu ED, Demir S, Bilginer Y, Ozen S. Comparison of patients with familial Mediterranean fever accompanied with sacroiliitis and patients with juvenile spondyloarthropathy. Clin Exp Rheumatol 2017;35(Suppl 108):124-7.

14. Watad A, Bragazzi NL, Adawi M, et al. FMF is associated with a wide spectrum of MHC class I- and allied SpA disorders but not with classical MHC class II-associated autoimmune disease: insights from a large cohort study. Front Immunol 2019;10:2733.

15. Ozer E, Seker D, Taner E, et al. The frequency of juvenile spondyloarthropathies in childhood familial Mediterranean fever. Clin Exp Rheumatol 2018;36:141-5.

16. Ozen S, Demirkaya E, Erer B, et al. EULAR recommendations for the management of familial Mediterranean fever. Ann Rheum Dis 2016;75:644-51. 